\title{
Writing Britain's Celtic History in the Nineteenth \\ Century: The Study of Folk Tradition by SIR John RhŶs
}

\author{
Angelika Heike Rüdiger
}

\section{Introduction ${ }^{1}$}

This paper investigates the way in which John Rhŷs used traditions of Welsh folklore, namely the one connected with the Tylwyth Teg, the Welsh fairies, in order to construct and support a hypothesis about the pre-history of the British Isles. The paper will show that Rhŷs used narrative motifs of fairy folktales and episodes from medieval Welsh and Irish literature involving supernatural characters as evidence in proof of his theory. Rhŷs' interpretation of both folktales and medieval texts can only be fully understood when the historical context and the (scientific) theories developed in the course of the nineteenth century, such as Charles Darwin's evolutionary theory on the origin of species and its extension to sociology, i.e. social Darwinism, are taken into consideration.

Moreover, it can be shown that the influence of nineteenth-century theories about the development of civilisation, especially those about the development of matriarchy and religion precipitated in Rhŷs' reading of folktales and narrative motifs. Therefore, this paper will first present a short biography of Sir John Rhŷs, followed by an introduction into the historical and theoretical context. Evolutionary social Darwinist ideas will be introduced, as they appear in various fields of academic studies in the nineteenth century. Indeed, social Darwinism and evolutionary theories were not restricted to the academic field, but also influenced the social discourse about important topics, as for example the question of women's rights in Victorian society, as social Darwinist hypotheses about women's rule in the prehistorical past were developed. The belief that folk tradition and custom are actually a window to the past-even to the prehistoric past-is another important building block in Rhŷs' model of prehistory and will be considered. A further section is dedicated to elucidating the connection between linguistic research, evolutionary ideas, and archaeological models of the prehistoric past. These considerations will also highlight the link between social Darwinist and imperialist ideas developing in the second half of the nineteenth century. After this introduction of the theoretical context, Rhŷs' model for the prehistory of the British Isles will be presented.

1. Sincerest thanks and gratitude to V.F.N., A.G. \& M.B.L. for support and encouragement. 
This discussion will also cover Welsh scholarly traditions of finding historical evidence in written or oral lore, as the development of Welsh scholarship, too, adds to the context of Rhŷs' theories.

\subsection{Sir John Rhŷs}

Sir John Rhŷs [formerly Rees] was born in 1840 at Aberceiro, Cwmrheidol, Cardiganshire. His father was Hugh Rees who was a farm worker and lead miner. John Rhŷs was educated at the British school, Ponterwyd, and later at a school at Pen-llwyn. After having attended Bangor Normal College he was appointed master at the British school at Rhos-y-bol on Ynys Môn (Anglesey). Rhŷs was mainly interested in the study of languages and antiquities, which led to his acquaintance with chancellor James Williams of Llanfair-yng-Nghornwy and Morris Williams 'Nicander' of Amlwch. It is supposed that one of the latter, presumably James Williams (Fraser \& Williams 2004), has introduced Rhŷs to Charles Williams, principal of Jesus College Oxford. In 1865 Rhŷs was granted a scholarship to that college. When studying at Oxford he used the summer holidays for trips to the continent and visited the towns of Paris, Heidelberg, Leipzig and Göttingen.

In the context of this paper it is noteworthy that he studied in Leipzig under Brockhaus, Curtius, Ritschel, and Leskien, and also met Schuchardt for the first time (Thorne 1986). Schuchardt and Leskien had both studied under Schleicher who saw parallels between the study of languages and the theory of Charles Darwin (Schleicher 1873: 7-8; Darwin 1859). Rhŷs stayed in touch with Schuchardt even when Rhŷs was in Oxford and Schuchardt stayed in Graz (Thorne 1986). In 1871 Rhŷs returned to Wales, and about this time he began to use the Welsh spelling of his name. He served as inspector of schools in Flint and Denbigh. In 1874 he gave series of lectures at Aberystwyth on Welsh philology (Rhŷs 1877). In 1877 John Rhŷs was appointed first professor of Celtic Studies at Oxford (Charles-Edwards 2019; Fraser \& Williams 2004; Williams 1959). The life and work of Rhŷs have been acknowledged by various authors such as Evans (1914-15), Hartland (1916), Stephens (1986), Evans (1995), Morris-Jones (1924/25), and Ifor Williams (1959). Most recent research focussing on Rhŷs' achievements in the field of linguistics has been published by Charles-Edwards (2013), Rodway (2019), Sims-Williams (2019), Lewin (2019), and Falileyev (2019). Dorson (1968), Davies (1990) and Wood (2005) focused especially on Rhŷs' influence on folk narrative research in Wales, for Rhŷs was not only a scholar of Celtic Studies, but also a folklorist and eager collector of Welsh folktales (Rhŷs 1901). Lewis (2016a; 2016b) focuses on the ethnological and anthropological aspects of Rhŷs' work. In the preface to Celtic Folklore: Welsh and Manx, Rhŷs describes his motivation for collecting folklore with the following words: "Towards the close of the seventies I began to collect Welsh folklore. I did so partly because others had set the example elsewhere, and partly in order 
to see whether Wales could boast of any storytellers of the kind that delight the readers of Campbell's Popular Tales of the West Highlands" (Rhŷs 1901: vii). Later he states in the same text:

It is a cause of genuine regret to me that I did not commence my inquiries earlier, when I had more opportunities of pursuing them, especially when I was a village schoolmaster in Anglesey and could have done the folklore of that island thoroughly; but my education, such as it was, had been of a nature to discourage all interest in anything that savoured of heathen lore and superstition.

(Rhŷs 1901: viii)

In 1888 John Rhŷs joined the Folklore Society, ${ }^{2}$ serving as its Vice-President from 1893 until his death in 1915. Whitley Stokes with whom he ran a copious correspondence was also a fellow of the Folklore Society since 1882, and the Irish texts edited by Stokes and Windisch provided Rhŷs with narrative episodes which he would use in proof of his ideas about the prehistoric past of the British Isles. ${ }^{3}$ John Rhŷs was certainly an outstanding scholar with his broad interest in the fields of language, archaeology and folklore. In the two last chapters of his Celtic Folklore. Welsh and Manx entitled 'Folklore Philosophy' and 'Race in Folklore and Myth' he conflates his hypothesis about the Celtic history of the British Isles with his studies on folklore by using narrative motifs from the fairy traditions to underpin his hypothesis. In what follows, I will show the way the evolutionary theories of the nineteenth century influenced Rhŷs in his making use of folklore.

\section{The theoretical context}

It is impossible to understand and discuss Rhŷs' model of prehistory of the British Isles without taking into account contemporary academic developments in Rhŷs' own and neighbouring fields of research. Therefore, the following part of this paper will briefly introduce the theories which have influenced Rhŷs' interpretation of folklore and which precipitated in his model of prehistory of the British Isles.

2. The Folklore Society (FLS) is a national association in the United Kingdom, founded in 1878. The homepage of the FLS states "The Folklore Society (FLS) is a learned society, based in London, devoted to the study of all aspects of folklore and tradition, including: ballads, folktales, fairy tales, myths, legends, traditional song and dance, folk plays, games, seasonal events, calendar customs, childlore and children's folklore, folk arts and crafts, popular belief, folk religion, material culture, vernacular language, sayings, proverbs and nursery rhymes, folk medicine, plant-lore and weather lore" (source: http://folklore-society.com, accessed 01.08.2019).

3. See below 4.2. For the correspondence between Rhŷs and Stokes see Russel (2019). Part of the correspondence, namely the so-called Sir John Rhŷs Papers: Letters and Cards from Whitley Stokes, 18711909 are available at the National Library of Wales. 


\subsection{Social Darwinism}

In 1859 Darwin published On the Origin of Species by Means of Natural Selection, or the Preservation of Favoured Races in the Struggle for Life (Darwin 1859). Darwin's theory of evolution was one of the greatest revolutionary ideas of the nineteenth century. Shortly after the publication of Darwin's theory Herbert Spencer compared the biological mechanisms of natural selection as described by Darwin to his economic theories (Spencer 1864:129). It was also Spencer who coined the word of the "survival of the fittest" (Spencer 1864: 444-445) ${ }^{4}$ and who considered social development as evolutionary process (Spencer 1864:347, 469). ${ }^{5}$ Thus, in the course of the nineteenth century, Darwin's evolutionary concept of natural selection was applied to human economic and social issues. This development resulted in theories labelled with the epithet of 'social Darwinism', which claimed that evolution was not only the driving force for the development of species, but also within economy, for the development of organisational forms of society and for cultural achievements, material or immaterial, such as the development of religion. The term 'social Darwinism' appeared in scholarly writing for the first time in 1877-1879 (Leonard 2009: 38-9; Halliday 1971; Rogers 1972). The evolutionary concept was also applied to justify imperialism and to back up the notion that there existed human races which were inferior to others. Benjamin Kidd writes in Social Evolution (1894) in a chapter on 'conditions of human progress,'

Yet neither wish nor intention has the power to arrest a destiny which works itself out irresistibly. The Anglo-Saxon has exterminated the less developed peoples with which he has come into competition even more effectively than other races have done in like case; not necessarily indeed by fierce and cruel wars of extermination, but through the operation of laws not less deadly and even more certain in their results. The weaker races disappear before the stronger through the effects of mere contact.

(Kidd 1894: 47)

4. "This survival of the fittest, which I have here sought to express in mechanical terms, is that which Mr Darwin has called "natural selection, or the preservation of favoured races in the struggle for life." (Spencer 1864:444-45).

5. "Among philosophical politicians, there has been spreading the perception that the progress of society is an evolution: the truth that 'constitutions are not made but grow', is a part of the more general truth that societies are not made but grow. It is now universally admitted by philologists, that languages, instead of being artificially or supernaturally formed, have been developed. And the historians of religion, of philosophy, of science, of the fine arts, and of the industrial arts, show that these have passed through stages as unobtrusive as those through which the mind of a child passes on its way to maturity... But though natural selection acts freely in the struggle of one society with another; yet, among the units of each society, its action is so interfered with, that there remains no adequate cause for the acquirement of mental superiority by one race over another except the inheritance of functionally-produced modifications" (Spencer 1864:347, 469). 


\subsection{The female rule}

During the mid-Victorian period the question of women's rights in society became a topic of general interest. The British Newspaper Archive ${ }^{6}$ proves this by the great number of newspaper articles which discuss women's franchise, suffrage, and women's emancipation and which were published in newspapers from places all over the United Kingdom in the second half of the nineteenth century. The evidence is far too copious to refer to every article, and therefore, the invitation of the Debating Society published in the University College of Wales Magazine is presented as a typical example for the public discourse about women's rights. The Debating Society had invited to a public debate 'On the Extension of the Franchise to Women' scheduled for 24th March 1880 and the proceedings of this debate were published in The University College of Wales Magazine (Winstanley, Angus \& Lloyd, 1879: 224-31).

The discussion of women's rights seems also to have precipitated in the field of folklore studies, for in her study on fairies and Victorian consciousness Silver points out that it might not be coincidental that the discussion about women's rights and an increased interest in and fondness of fairy mistress tales culminate at the same time (Silver 1999: 89). Indeed, the fairy mistress tales show marriage as a contract between husband and wife. If the husband fails to correspond to the conditions of the contract, his fairy wife will leave him. In the case of the legend of Llyn y Fan Fach, the fairy wife takes all her property with her and also every wealth which has originated in the property she brought into the marriage (Rhŷs 1901: 10). ${ }^{7}$ A collection of Welsh fairy mistress tales can be found in the first chapter of Rhŷs' Celtic Folklore: Welsh and Manx (Rhŷs 1901:1-74). It is entitled 'Undine's Kymric Sisters' and suggests that Rhŷs, too, was intrigued by this subject. He chose lines from de la Motte Fouqué's Undine which is a literary fairy tale (Kunstmärchen) based on traditional narrative motifs taken from fairy mistress tales as preface for this chapter (Rhŷs 1901:1). ${ }^{8}$

In the context of this paper, it will be shown that Rhŷs relied indeed on these fairy mistress tales as evidence in proof of his own hypothesis about the aboriginal population of the British Isles. Following the arguments of Silver, it seems that the fairy mistress tales offered the Victorian society a way of musing about pressing questions, such as the right of women to keep their property, even in the case of divorce, or women's right to divorce if the husband does not keep to the conditions

6. Available at www.britishnewspaperarchive.co.uk, accessed 01.08.2019.

7. For a study on the transmission of this legend see Davies 2018. About fairy bride legends in Wales see also Wood 1992.

8. ,Undine, liebes Bildchen du,/Seit ich zuerst aus alten Kunden/ Dein seltsam Leuchten aufgefunden/Wie sangst du oft mein Herz in Ruh!' ['Undine, you dear little picture/ since I have found your strange shining from old tales for the first time, how often have you sung my heart to peace', my translation] 
under which the woman had agreed to marriage. The fairy tales allowed for addressing these questions in traditional narrative motifs (Silver 1999: 89). Therefore, as the role of women in society was a central question to be addressed by society in the nineteenth century, it had to be expected that research, too, would address the question of women's role in society in some way. Indeed, we can observe that in the nineteenth century anthropological evolutionary theories about the rule of women were postulated. As early as 1861 Bachofen had presented Das Mutterrecht in which he developed a theory about the evolution of forms of social organisation considering especially the role and predominance of either the male or the female gender. Bachofen believed that the earliest and most primitive form of social organisation was hetaerism, a form of society which does not know wedlock.

Auf der tiefsten Stufe des Daseins zeigt der Mensch neben völlig freier Geschlechtsmischung auch Oeffentlichkeit der Begattung. Gleich dem Thiere befriedigt er den Trieb der Natur ohne dauernde Verbindung mit einem bestimmten Weibe vor Aller Augen.

(Bachofen 1861: 10)

On the lowest level of existence, man exhibits next to a completely free mixing of sexes also sexual intercourse in public. Like an animal he satisfies the urges of nature without lasting relationship with a certain woman in plain sight.

(my trans.)

The following stage of social organization was matriarchy, which was finally followed by the patriarchal society - the most advanced form of society according to Bachofen.

Das Mutterrecht gehört dem Stoffe und einer Religionsstufe, die nur das Leibesleben kennt und darum, wie Bellerophon, verzweifelnd vor dem ewigen Untergang alles Gezengten trauert. Das Vaterrecht dagegen gehört einem überstofflichen Lebensprinzip. Es identifiziert sich mit der unkörperlichen Sonnenkraft und der Anerkennung eines über alle Wechsel erhabenen, zu den göttlichen Lichthöhen durchgedrungenen Geistes.

(Bachofen, 1861: 7)

The mother right belongs to the material matter and to a stage of religion which knows only the life of the body and therefore, like Bellerophon, despairingly mourns the eternal decay of all that was begotten. The father right, however, belongs to the principle of life surpassing the material matter. It identifies with the non-corporal power of the sun and the acknowledging of a spirit which is above all changes and has reached the divine heights of light.

(my trans.) 
Lewis Henry Morgan developed a theory of social evolution which came to conclusions similar to Bachofen (Morgan 1877). In Ancient Society, Morgan defines various stages of human social development, namely, that of savagery (low, middle, upper), barbarism (low, middle, upper) and civilisation. Morgan claims that people he classed as savage or as barbarian of lower status, such as the Australian tribes, share their wives and husbands in common (Morgan 1877: 49). Groups defining their descent by the female line are found with peoples who live on the stage of middle savagery to upper barbarism (Morgan 1877: 66-7), whereas the patriarchy is found in the more developed stages of society. ${ }^{9}$ Engels, too, shared Bachofen's and Morgan's opinion that matriarchy preceded the patriarchal organisation of society (Engels 1886: 16-43). Hence, a people living in the stage of matriarchy would be classed as belonging to an inferior stage of cultural development.

\subsection{Magic versus religion. Evolutionary theories on religion}

When analysing Rhŷs' Lectures on the Origin and Growth of Religion as Illustrated by Celtic Heathendom (Rhŷs 1888), it can be shown that Rhŷs has been strongly influenced by Max Müller. Müller's Lectures on the Origin and Growth of Religion as Illustrated by the Religions of India (1878) provided the pattern for Rhŷs' own work about Celtic religion. Rhŷs, too, uses a comparative mythological approach. Especially, Lecture V ('The Sun Hero') of Rhŷs' work demonstrates how the author applied Max Müller's solar myth theory to Celtic material (Rhŷs 1888: 383578)..$^{10}$ The lecture identifies a number of characters from Irish and Welsh medieval literature as characters who originated in Celtic solar deities. However, towards the end of the nineteenth century Müller's theories became less popular, and new evolutionary models for the development of religion were in the ascendant. Tylor had applied evolutionary theories to anthropology and the development of religion.

In Primitive Culture, he argued that religion developed from animism to polytheism and ended in the most developed state of monotheism (Tylor 1871; id. 1920). His work had influenced James Frazer who published the first edition of The Golden Bough presenting another evolutionary model in 1890 (Frazer 1890). He claimed that in primitive societies religion was missing, but primitive man practised magic. For Frazer, magic was but a mock image of science, based

9. An on-going argument in Victorian Britain should be noted with respect to whether the Britons were inferior to the Anglo-Saxons. According to Morgan, the Britons belonged to the stage of middle barbarism, whereas the Germanic tribes he classed as living on the stage of upper barbarism. The marker for the discrimination should be the use of iron, but Morgan finds that the Britons have to be classed rather with the people living on a stage of middle barbarism because of their 'domestic institutions', i.e. alleged plural marriages according to Caesar (Morgan 1877:11, 483). I will discuss this further.

10. For a survey on Müller's solar myth theory and a criticism of this theory see Carroll (1988). 
on a rudimentary and incomplete understanding of the physical world.

Hence, when at a late period the distinction between religion and superstition has emerged, we find that sacrifice and prayer are the resource of the pious and enlightened community, while magic is the refuge of the superstitious and ignorant. But when, still later, the conception of the elemental forces as personal agents is giving way to the recognition of natural law, then magic, based as it implicitly is on the idea of a necessary and invariable sequence of cause and effect, independent of personal will, reappears from the obscurity and discredit into which it had fallen, and by investigating the causal sequences in nature, directly prepares the way for science.

(Frazer 1894: 32)

Religion, however, according to Frazer, was based on the assumption of the existence of a deity who may be addressed, though the outcome of the address was not predictable, as religion was not bound by the laws of nature, but instead represented something akin to a bargain between two individuals.

This view is voiced most concisely by Frazer in the 1922 edition of The Golden Bough in the 'Magic and Religion' chapter:

By religion, then, I understand a propitiation or conciliation of powers superior to man which are believed to direct and control the course of nature and of human life. Thus defined, religion consists of two elements, a theoretical and a practical, namely, a belief in powers higher than man and an attempt to propitiate or please them.

(Frazer 1925: 50)

Rhŷs' shift from Max Müller's theories to the new evolutionary theories becomes obvious in his preface to Studies in Arthurian Legend (1891):

Most of the following chapters arose out of my Hibbert Lectures on Celtic Heathendom which were delivered in the year 1886. In consequence of that origin they take for granted the same views, in the main, as to Aryan mythology. It is hoped, however, that the reader who disapproves of those views, will not regard me as now perpetrating a fresh offence, though I have been obliged to continue the use of some of the terms of the Solar Myth Theory. They are so convenient; and whatever may eventually happen to that theory, nothing has yet been found exactly to take its place. Nevertheless, we are possibly on the eve of a revolution in respect of mythological questions, as Mr. Frazer's Golden Bough seems to indicate.

(Rhŷs 1891:v-vi) 
In Celtic Folklore, the impact of both Frazer's and Tylor's work on Rhŷs' prehistoric theories is obvious, as Rhŷs explicitly refers to the work of both scholars in the chapter entitled 'Race in Folklore and Myth' and in which he connects the Welsh fairy traditions with prehistory (1901: 639-688).

\subsection{Folk custom as survival of ancient religion}

Using folk traditions as source of evidence when drafting a hypothesis of prehistory was in accordance with the results of anthropological studies. Tylor believed that custom and beliefs of primitive culture survived in nursery folklore, popular sayings, custom and superstitions (Tylor 1871:15-16). He could rely on the earlier work by the Grimm Brothers (1835:9). Frazer, too, followed the idea that folklore holds survivals of pagan custom: "Hence every inquiry into the primitive religion of the Aryans should start from superstitious beliefs and observances of the peasantry" (Frazer 1894: vii-xi). Thus, folklore adopted a new importance as hoard of information about the pagan past which had to be properly exploited and interpreted. In the long run this understanding of folklore was certainly one factor which would lead scholars into suggesting that beliefs of the common people in Britain consisted only of a thin veneer of Christianity covering pagan beliefs surviving from the pre-Christian times, aptly summarised by Hutton:

During the first two-thirds of the twentieth century, it was commonplace among historians that the common people of medieval England had remained substantially pagan in their religious beliefs. Christianity, according to this view, was essentially the faith of the elite, with the populace embracing what was at best a dual allegiance to the new and old religion.

(Hutton 2011)

However, Hutton finds that today these romantic theories must be rejected, for genuine survivals from the pagan past seem to be extremely rare, if such survivals as the names of the days of the week, the names of the months, classical motifs persisting in medieval literature and art, classical influences on the architecture of the churches and similarities between pagan and Christian ritual are excluded. The survival of a pre-Christian religion has to be rejected (Hutton 2011; 1991: 324-327).

Another development which led to an increased appreciation of folklore was closely connected with the progressing industrialisation, for during the nineteenth century, problems related to industrialisation began to show, such as the pollution of the environment and increased urbanisation with the development of a proletarian class living under very poor conditions. As a reaction, life in the countryside was idealised and romanticised (Williams 1973; Keith 1975; Wiener 1981; Bennett 1993). Both the wish to believe in pagan survivals and the idealisation of country 
life and folk beliefs and customs are virtually a reaction to the challenges of industrialisation and scepticism towards conventional Christianity which did not seem to answer the spiritual challenges in the second half of the nineteenth century. After all, at the end of the nineteenth century, Rhŷs considered folklore as a portal to the prehistoric past, and hence as a repository of evidence for his theories.

\subsection{Language, culture and race}

In the previous sections I have dealt with various evolutionary theories which were mainly based on the nineteenth century ethnological research. Rhŷs' academic education was based on the studies of languages, including linguistics and philology (Thorne 1986). In this field, evolutionary theories flourished, too, and were merged with earlier considerations concerning the Celtic languages and their origin. Research in the origin of languages leads inevitably to investigations about the people who spoke those languages, and, as a consequence, the results in the field of archaeology must be considered when a model about the spread of languages in prehistoric times is drafted. Therefore, this section will concisely introduce those theories on language, archaeology and race which prepared the ground for Rhŷs' assumption that prehistory of the British Isles could be presented as several stages of invasion with each of the invading peoples installing a more advanced culture.

In this vein, it was Edward Lhuyd (1660-1709) who published Archaeologia Britannica in $1707 .{ }^{11}$ He recognised similarities between Welsh, Cornish, Gaelic (Irish and Scottish), Breton and Gaulish and identified them as Celtic languages. He also recognised that these languages could be grouped in two families; namely, P-Celtic or Brythonic (Welsh, Breton, Cornish) and Q-Celtic or Goidelic (Irish, Scots Gaelic, Manx). This left the scholars with two questions: how these languages had been introduced to the British Isles, and-after the spread of Darwinian ideas in the field of linguistics - how could the Celtic languages be ranked in comparison with other languages? Darwinian ideas surfaced quite quickly in the field of linguistics. Connecting ethnology and linguistics, however, had a tradition which predated the Darwinian theories. In 1831, James Cowels Prichard published The Eastern Origin of the Celtic Nations proved by a Comparison of Their Dialects with the Sanskrit, Greek, Latin, and Teutonic Languages Forming a Supplement to Researches into the Physical History of Mankind (Prichard 1831). Prichard refers explicitly to Edward Lhuyd, but also to German scholars, namely, to Friedrich and August Schlegel, who had developed comparative language studies, and to Jacob Grimm. Prichard understands the use of cognate languages as marker for racial relationship between people and highlights the close connection between ethnology and linguistics.

11. For biographical details on Edward Lhuyd see Roberts (2009) and Williams (2009). 
The examination of cognate languages, while it points out their resemblances and proves the affinity of the races of man of which they formed the vernacular speech, seldom fails at the same time to elucidate, in a greater or lesser degree, the structure of the respective idioms themselves [...]

(Prichard 1831: vi)

A German scholar who fused the Darwinian theory with linguistic research was August Schleicher, who had published an essay entitled 'Die Darwinische Theorie und die Sprachwissenschaft' (Schleicher 1873). He sees parallels between biological processes in nature and the development of languages, so that he even postulates that 'Glottik', die Wissenschaft der Sprache, is a natural science (Schleicher 1873: 7). Schleicher had been the academic teacher of Leskien who taught Rhŷs, and Rhŷs' friend Schuchardt had been a pupil of Schleicher. It is therefore possible that Rhŷs had been aware of August Schleicher's theory. Schleicher postulates:

Desto unbestreitbarer ist aber auf sprachlichem Gebiete die Entstehung der Arten durch allmähliche Differenzierung und die Erhaltung der höher entwickelten Organismen im Kampfe ums Dasein.

(Schleicher 1873: 33)

Even more, it is no question of debate in the field of language that the species come into being by gradual differentiation and by the preservation of the higher developed organisms in the struggle for life.

(my trans.)

However, human race is not only characterised by the languages used, but also by the artifacts it leaves behind. In 1836, Christian Jürgensen Thomsen had voiced the view that the development of mankind was determined by the constant improvement of tools. In Ledetraad til Nordisk Oldkyndighed udgiven af det kongelige Nordiske Oldskriftselskab he refined the previously accepted Three-Age System by introducing the Stone, Bronze and Iron Age as a chronological system for classifying archaeological artifacts (Thomsen 1836). His work was translated into English by Egerton in 1848 as Guide to Northern Archaeology (Egerton 1848). About the middle of the nineteenth century Scandinavian scholars developed the method of craniology further and applied it to skulls found by archaeologists.

Thus, both craniology and the paradigm of the Three-Age System were used to interpret prehistoric human remains and to create a theory of Europe's prehistoric past. In 1846, both the Three-Age System and craniology were made available to the British and Irish public by J.J.A. Worsaae (Worsaae 1849; Birkhan 2009: 453; Morse 1999). One important consequence which would affect Rhŷs' theories was the fact that the Three-Age System put an end to the romantic view popular among 
the nineteenth-century scholars who argued for a connection between druids and dolmens and other megalithic remains from the Neolithic period. Another theory adopted from Scandinavian scholars was the belief that Europe has been populated by non-Indo-European Stone-Age tribes (Kyllingstad 2012). John Beddoe, a Welsh archaeologist, found the studies of craniology insufficient for characterising the races of the British Isles and extended his line of inquiry to pigmentation, introducing an index of nigrescence (Beddoe 1885) ${ }^{12}$. In the second half of the nineteenth century, MacRitchie (1851-1925), a Scottish folklorist and antiquarian, the founder of the Gypsy Lore Society and later the Vice-president of the Society of Antiquaries of Scotland, strongly promoted a theory which claimed that the aboriginal population of the British Isles consisted of pygmy tribes.

MacRitchie is also credited as the founder of the fairy euhemerization theory which considers the fairies to be a pre-Bronze Age people, a race connected to the Ainu, Saami and Inuit, the latter called 'Lapps' and 'Eskimos' according to MacRitchie's nineteenth-century terminology (MacRitchie 1890; 1892; 1893; 1894). However, MacRitchie was not alone, for other scholars promoted the idea of a pygmy population of Europe as well; one of these scholars who Rhŷs refers to was Kollmann (1894), who believed to have discovered archaeological evidence to support this theory. ${ }^{13}$ As will be argued below, Rhŷs' ideas about race and fairy lore hold a number of elements influenced by MacRitchie's theories (MacRitchie 1890; MacRitchie 1893). ${ }^{14}$

It can be added that theories about inferior autochthonous races were given a higher credibility by the discovery of tribes living without the knowledge of metallurgy or agriculture in the rainforests and other remote areas in Africa, Asia and Australia in the course of the nineteenth century. Therefore, Dorson comments on Alfred Nutt's address to the Folklore Society in 1899: "They [the British folklorists, A.R.] possess the primitive stratum of 'archaic literature' in a far better state of preservation than it was found in Germany, France, Scandinavia, or Russia. Their imperial position brought the savage races of the world under the same rule as the peasant at home" (Dorson 1968: 233). Rhŷs' predilection for the pigmy theory, however, was not shared by other eminent members of the Folklore Society. Andrew Lang challenged the pygmy theory (Kirk 1933: 17), and so did Hartland (1891:348-52). The latter

12. Edwards \& Gould (2013) study the transition from antiquarian interest to archaeological research in Wales.

13. Modern archaeology, however, no longer supports these ideas. Indeed, the theory of pygmies as British aborigines was rejected as early as 1907 by the Irish scholar Holmes (1907) in the absence of reliable archaeological evidence.

14. Wood draws attention to Rhŷs being influenced by MacRitchie (Wood 2005) but, surprisingly, Morris-Jones (2002) claims that Rhŷs' reached his conclusions independently. Yet, Rhŷs himself refers to MacRitchie's work in a footnote (Rhys 1901: 680). On the dwarf races, Rhŷs obtained additional information from A.C. Haddon (Rhŷs 1901: 683-84). 
certainly influenced Rhŷs strongly, according to the references in Celtic Folklore (Rhŷs 1901: 18, 268, 359, 360,406 ,605). Further major influences were Gomme (Rhŷs 1901: 103, 310, 346, 358, 360) and Clodd (Rhŷs 1901: 584, 585, 593, 598, 607, 628). All three folklorists favoured the evolutionary theories stressing the difference between primitive and civilised man (Dorson 1968: 221, 245, 249).

But how did the evolution or advancement of culture come about? In the remainder of the section, I will consider assumptions made about the process of passing on and development of advanced cultural achievements, which had influenced Rhŷs, namely that the achievements of civilisation had to be learned from more advanced people. As early as 1845 Robert Chambers draws attention to this lack of belief in self-originated development and cautions against it in Vestiges of the Natural History of Creation:

It is also alleged that we know of no such thing as civilisation being ever self-originated. It is always seen to be from one people to another. Hence, of course we must infer that civilisation at the first could only have been of supernatural origin. This argument appears to be founded on false premises, for civilization does sometimes rise in a manner clearly independent amongst a horde.

(Chambers 1845: 208)

Combining this lack of belief in the self-originated civilisation with the Three-Age System enforces the assumption that an advancement of culture is only possible by close contact between two peoples, one of which has already reached a higher cultural level. This contact could be brought about peacefully by trading or by a military conquest. Therefore, it seemed a reasonable idea to draft the prehistoric past of the British Isles as a series of invasions and conquests, especially if the academic élite wanted to see itself as the descendants of culturally advanced people. William Boyd Dawkins (1880:247) would express this attitude in his Early Man in Britain and His Place in the Tertiary Period:

We have to chronicle in the Prehistoric period the changes wrought in Europe by the invasion of new peoples, and the appearance of new civilisations.

(Dawkins 1880: 247)

However, this virtually denies the autochthonous people both the possibility of development by taking up new impulses from other peoples and developing them further and the ability of innovation. Taking one step further this view of civilisation spreading by contact with more advanced and hence more successful 
people was embedded in imperial thinking..$^{15}$ The idea of successful people moving eastward and northward and creating empires shows in Benjamin Kidd's Social Evolution:

We follow the path of the Empire from the stagnant and unchanging East, westwards through peoples whose pulses beat quicker and whose energy and activity become more marked as we advance... A similar lesson is emphasised in the northward movement of rule and empire throughout historic times.

(Kidd 1894:56-7)

In this we can witness how social Darwinist ideas were merged with imperialist attitude, as described by Brantlinger (2018). ${ }^{16}$ Moreover, small nations came under pressure in retaining their place in history and society, as they were stigmatized as inferior and backward races (Evans \& Pryce 2013: 234).

\section{Rhŷy' model of Britain's prehistory as presented in Celtic Folklore: Welsh and Manx}

The following section will introduce Rhŷs' model of prehistory which draws on the contemporary theories that have been discussed above.

\subsection{The Stone Age population - The lowest stratum: the mound dwellers}

Rhŷs found himself in agreement with the Three-Age Theory: Rhŷs believed in Wales being populated by the pygmies in the Stone Age, similarly to the pygmy tribes discovered in the tropical forests during the nineteenth century:

First comes the race of the mound folk, consisting of the short swarthy people variously caricatured in our fairy tales. The real race of the little people forms the lowest stratum which we can reach, to wit, at a level no higher, seemingly, than that of the present-day natives of Central Australia.

(Rhŷs 1901: 683)

We can also recognize that Rhŷs not only adhered to the pygmy theory as postulated by MacRitchie $(1890,1892,1893$, 1894), but had also accepted the index of nigrescence introduced by Beddoe into his view of the prehistory of the British Isles (Beddoe 1885: 1-9). According to Rhŷs, some individuals of this pygmy population survived in hidden and remote places of the British Isles into the historical period, but remained at their own stage of development, i.e. that of the Stone Age. In his

15. For a critical discussion of the invasion hypothesis in British archaeology see Clark (1966).

16. For a more detailed introduction into the field of British Imperialism see Johnson (2003). 
view, the little people, the fairies, were actually a memory of the race of people living on a very low level of civilisation.

The sallowness of their skins and the smallness of their stature, their dwelling underground, their dislike of iron, and comparative poverty of their homes in the matter of useful articles of furniture, their deep-rooted objection to the green sward being broken up by the plough, the success of the fairy wife in attending to the domestic animals and to the diary, the limited range of the fairies' ability to count; and lastly, one may perhaps mention the using a language of their own,which would imply a time when the little people understood no other, and explain why they should be represented doing their marketing without uttering a syllable to anybody.

The attribution of these and similar characteristics to the fairies can scarcely be all mere feats of fancy and imagination: rather do they seem to be the result of our ancestors projecting on an imaginary world a primitive civilization through which tradition represented their own race as having passed, or, more probably a civilization in which they saw, or thought they saw, another race actually living.

(Rhŷs 1901: 659)

After some considerations concerning place-names and tribal names which contain probably the element 'cor' (dwarf), Rhŷs concludes: "There we should have accordingly to suppose the old race to have survived so long and in such numbers, that the Celtic lords of southern Britain called the people of that area by a name meaning dwarf" (Rhŷs 1901: 675). According to Rhŷs, the lake legends about the lady of Llyn y Fan Fach contrast clearly the advanced and the primitive civilisation, not only by the fairies, i.e. the primitive people being unable to make proper bread, but because these supposed pygmy tribes were organised in a matriarchal society (Rhŷs 1901: 660-661). He draws this conclusion from his observation that the shepherd wooing the fairy lady lives as a son of a widowed mother: "Seemingly, he belongs to a primitive society were matriarchal ideas rule and where paternity is not reckoned" (Rhŷs 1901: 661). Moreover, according to some Welsh folk tradition the fairies were all women. Rhŷs also refers to Irish material, namely to Condla's journey to the realm of the ever-living ones, where a race of women and maidens alone lived.

Now what people could have come by the idea of a race of women only? Surely no people who considered that they themselves had fathers. It must have been some community so low in the scale of civilisation as never to have had any notion whatsoever of paternity: it is their ignorance that would alone render possible the notion of a race of all women.

(Rhŷs 1901: 662) 


\subsection{The Neolithic Cultures: The Picts, a Warlike Stock}

Furthermore, Rhŷs assumed that another people followed, living at the stage of a Neolithic culture. ${ }^{17}$ These people practised magic, but had no religion. Rhŷs supposes that "they got their magic and druidism from the dwellers of the síds" (Rhŷs 1901: 685). Their magi, their sorcerer-priests were the druids, who were-according to Rhŷs - similar to the shamans of Mongolia (Rhŷs 1901:631). Rhŷs beliefs to identify the druids as protagonists of a non-Aryan population: "The belief in rebirth generally seems to fit as a part of the larger belief in the transmigration of souls which is associated with the teachings of the ancient druids, a class of shamans or medicine-men who were probably, as already hinted, not of Celtic or Aryan origin" (Rhŷs 1901: 658).

This non-Aryan race was warlike and it had "a notion of paternity, though, on account of of its promiscuity, it has to reckon descent by birth" (Rhŷs 1901: 684). In the eyes of Rhŷs, these characteristics were a sign of a more advanced stage of culture. We see that Rhŷs' opinion mirrors the theories by Bachofen, Morgan and Engels and those of Frazer and Tylor (see sections 2.2 and 2.3 above). Rhŷs believed this race to be the Picts (Rhŷs 1901: 637-8, 684; Rhŷs 1884: 69-70). Accordingly, these 'Picts' had Lybian or Iberian affinities, which implied that they came from the Western Mediterranean region to the British Isles (Rhŷs 1901:682, 684). It is obvious that Rhŷs' ideas about the Picts are indeed very far from our knowledge about the historical Picts (Clarkson 2012; Hudson 2014). Some of his colleagues were not happy with his theories about the Picts: Whitley Stokes, for instance, criticised Rhŷs' theories about the Picts elaborated in The Welsh People (1900) in a letter:

I ought to have acknowledged it long ago, but, to tell you the truth, the chapter on the Pictish question made me so unhappy that I could not bear to write to you on the subject. I seem to feel as poor Caleb Balderstone felt when he saw the Master of Ravenswood ride recklessly into the fatal quicksand!

(Russel 2019: 31)

\subsection{The Iron Age - the Celts - two Aryan peoples}

The arrival of the Celtic tribes on the British Isles are treated only passingly in Celtic Folkore, as Rhŷs seems to take the knowledge of the reader about the Goidels and Brythons as granted. Rhŷs believed that two Aryan (i.e. Indo-European) races arrived in succession in two waves of invasion and introduced an Iron Age culture (Rhŷs 1884:4). Rhŷs explained that the aboriginal population influenced the

17. "I am inclined to think that in pre-Aryan times a Neolithic race, which may be termed IberoPictish, occupied Western Europe from the Straits of Gibraltar to the Pentland Firth and the Danish Islands of the Baltic" (Rhŷs 1890/91:121). 
Celtic tribes in terms of language and culture; however, the non-Aryan heritage remained comparatively small in the case of the Brythons as they had arrived later (Rhŷs 1890/91: 22). We see that Rhŷs' model does not only comprise three stages of cultural development, but he also assumes that every new level of cultural development is connected with the arrival of a new race on the British Isles (Rhŷs \& Brynmore-Jones 1900: 11).

\section{Fairy folklore as evidence to back up Rhŷs' model of Britain's past}

\subsection{The 'Little People' - A pygmy people living in hidden places?}

Here, the following question arises: what evidence did Rhŷs consider to support his theory and what was his aim?

Being not only a linguist, but also a nineteenth-century folklorist Rhŷs supported his opinions with evidence from folk traditions, namely the traditions connected with the fairies, as citations from his works provided in section 3.1 demonstrate. Rhŷs used elements of fairy traditions to support his model of Britain's prehistoric past, for he assumed that the tales about the Tylwyth Teg contained elements of imagination and ancestor worship as well as historical elements, so that the tales represented at least partly a collective memory of prehistoric tribes (Rhŷs 1901: 659). For Rhŷs, the matter was obvious: the pygmies are the 'little people', $y$ Tylwyth Teg, the fairies, especially when they are reported to be ugly (Rhŷs 1901: 685). In addition to the pygmy theory of MacRitchie, the Victorian motif of the ugly dwarf, the ugly person from an underdeveloped people, which can be traced in Victorian literature, becomes apparent (Silver 1999: 117-47).

Another famous motif which characterizes supernatural, demonic characters is the fear of iron. Rhŷs also interprets the motif of the Tylwyth Teg rejecting iron as evidence of the fairies representing a Stone Age population (Rhŷs 1901: 660). However, the motif that iron is taboo for supernatural characters, such as fairies, ghosts or demons, is a widespread narrative motif in European tradition. We find it as early as the writings of Pliny (Lawrence 1898). In fact, it is one of the main motifs showing the difference between the world of human beings and of the supernatural domain: whatever is most useful for human society, be it iron, salt or fire, is taboo for the otherworld, i.e. for non-human beings. The iron taboo is found in the folklore of Scotland, Ireland and Cornwall. But it is also reported for many parts of Germany and Scandinavia. In Poland and the Ukraine, iron is also used as a protective agent against supernatural powers. Lawrence has also collected examples from the Arabian region - where iron is used as a protective charm against the Jinn. It is noteworthy that iron does not only work as protective charm against fairies or comparable supernatural beings, such as the Scandinavian troll and the Arabian Jinn, but also against the devil in Poland and the Ukraine, and against 
witchcraft in Germany, against the evil eye in Sicily, or in Germany as protection against illnesses (Lawrence 1898: 26-38).

However, the idea that the narrative structures and folk traditions could hold a meaning different from representing a distorted historical tradition or could have a social function other than being a collective memory is not part of Rhŷs' methodology in assessing fairy traditions. When applying the euhemerization theory to Welsh folk beliefs, Rhŷs understood fairy folk tradition as a repository of historical memories. For Rhŷs and folklorists adhering to the euhemerization theory, fairy attributes and narrative motifs are possibly distorted, but nevertheless fragments of real, historically significant evidence.

Rhŷs was not the first to euhemerise the fairies; James Cririe had already done so in his Scottish Scenery (1803:347). He thought the fairies represented the druids, and a similar idea was voiced by the Peter Roberts (1815: 192-201). In Popular Cambrian Superstition, Roberts claimed that the fairies were actually the druids who had gone into hiding after the Roman conquest. Rhŷs was certainly familiar with these ideas as he refers to Roberts' Popular Cambrian Superstitions in the bibliography to Celtic Follkore. However, the antiquarians of the eighteenth and early nineteenth century did not consider the druids to have been the magicians of a primitive autochthonous, non-Celtic people. Indeed, the time of druids had been styled a golden, pre-Roman period of wisdom and scholarship in Wales as described in Theophilus Evans' Drych y Prif Oesoedd first published in 1716 (Evans 1902: 22).

Folklore studies as a means for collecting antiquarian knowledge had a tradition predating the evolutionary theories by Tylor or Frazer. The idea that studies of folklore or antiquities were a subject in its own right began to develop strongly during the eighteenth century, but the view that folk tales and customs could eventually provide access to the past can be dated to the sixteenth century. William Camden (1551-1623) maintained that legends could be based on historical evidence (Dorson 1968:4). George Owen shared his friend Camden's interest in folklore (Thomas 1975: 35) as well as Rhŷs Meurig of Cottrell (Williams 1959). Dorson finds "the moral for the later antiquaries is plainly marked: the factual story behind the Roman ruin may still survive, dipped in legend, on the lips of the natives, and offer clue to the historian" (Dorson 1968: 4).

Edward Lhuyd (1660-1709), a widely known scholar researching Welsh antiquities followed this strategy (Jones 1959) and reported on customs and traditions in his Design (Roberts 2009: 40), combining oral traditions with linguistic and archaeological studies. His methodology of finding evidence about the past is similar to Rhŷs' method combining evidence from various fields of research in his Celtic Folklore. Lhuyd stayed critical and rejected popular explanations of phenomena which contradicted either scientific or historical knowledge (Roberts 2009: 40) and treated folk 
tradition with caution. In Archaeologia Britannica however, he maintained the possibility of druidic teaching surviving in poetry:

The sort of Verse I find most common amongst our oldest Remains, is that is called Englyn Milur in Jo. Dav. Rhŷs's Grammar p. 184. And in regard I have (tho' but rarely) heard the same in the shire of Argile in Scotland, and also in Cornwal, I am apt to conclude it one of the most Ancient, if not the very oldest sort of Verse we ever had, and that 'twas in this sort of Meeter the Druids taught their Disciples.

(Lhuyd 1707, 250-1)

At the end of the eighteenth century the Morris Brothers, Lewis Morris (1701-1767), Richard Morris (1703-1779) and William Morris (1705-1763) had a great impact on antiquarian and folklore studies.

In 1751 Richard Morris founded the Cymmrodorian Society. Lewis Morris adopted the idea that the ancient Celtic culture could be equated with druidism. As the Morris brothers were in contact with a great number of people their views proved to be influential (Thomas 1975: 35-6, Morgan 1981: 60-1,85; Jenkins 1959a).

However, a supposed connection between the literary tradition of the bards and the druids had not been accepted unanimously among Welsh scholars, although the idea of a connection between the bards of medieval Wales and the druids of the classical past before and during the Roman conquest had a long standing tradition. The idea was voiced originally by Sir John Price in Historiae Brytannicae Defensio (Price 1573:11) who read the word prydydd as prydruid. Already the Tudor scholar Maurice Kiffin expressed his disbelief that any druidic tradition had been handed down to the Welsh bards, and almost a century later Henry Vaughan expressed the same scepticism (Hutton 2009: 56). The idea of Welsh literature having preserved fragments of druidical lore shines up in the writings of Lhuyd, as we have seen above, and this assumption was taken up by Lewis Morris. Thus, at the beginning of the nineteenth century, the idea that druidical knowledge was still alive in some form in medieval Welsh literature lingered on. The Morris Brothers, William Owen Pughe and Iolo Morganwg (Edward Williams) were driven by the romantic desire to revive the past from medieval texts and to anchor the contemporary Welsh culture and language firmly in this imagined and partly also fabricated romantic past (Wood, 1997: 97). Iolo Morganwg took this desire to the extreme. He believed it was possible to revive the traditions of the druids with the help of medieval Welsh poetry and prose (Jenkins 2009, Constantine 2007). This romantic theory of the Welsh past found ardent followers, among them ap Ithel-Rev. John Williams (Jenkins 1959b). ${ }^{18}$

18. He is known to have tried to silence Thomas Stephens who dared to question historical truth 
After all, when Rhŷs started his work, he confronted a long established intellectual tradition of retrieving the past from the analysis of medieval texts and documents. As Lectures on the Origin and Growth of Religion as illustrated by Celtic Heathendom shows, Rhŷs, too, believed that the old medieval texts were a window on the Celtic past (Rhŷs 1888), but he did not consider the druids as the idealised keepers of Celtic wisdom and tradition. On the contrary (see also section 3 above):

Here I may be allowed to direct attention to the two following facts: the druid, recalling as he does the magician of the Egypt of the Pentateuch and the shaman of the Mongolian world of our own time, represented a profession probably not of Celtic origin.

(Rhŷs 1901: 631)

This altered image of the druids has to be attributed to the archaeological ThreeAges Theory and social Darwinist theories.

In the field of racial theories, too, Rhŷs could rely on the work of Welsh scholars who had tried to establish a racial theory about the inhabitants of the British Isles. Thomas Price (Carnhuanawc; 1787-1848) had composed An essay on the physiognomy and physiology of the present inhabitants of Britain; with reference to their origin, as Goths and Celts (1829). This essay was written as a challenge to the ideas of the Teutonist Pinkerton (Rees 1959). Price's work is mainly descriptive and still far from the three-age theory with the differentiation between the different people according to the level of their civilisation, instead Price focuses on the physical features (Price 1829). In the second half of the nineteenth century, however, racial evolutionary theories had been established which prompted Rhŷs to understand the 'little people' of the fairy tales as the British aborigines, and to interpret their ugly appearance described in the fairy tales, especially in the changeling-type tales, as typical physiognomy of an inferior race (Rhŷs 1901: 667). He even believed to detect aboriginal genetic heritage with his own contemporaries:

It was that of a wife of a farmer living near Nefyn, in West Caernarvonshire. It was whispered that she was a changeling, so I am inclined to regard her as no other than one of the representatives of the same aboriginal stock to which one might conjecture some of her neighbours also belong to [...]

(Rhŷs 1901: 667)

of the legend of Madog ab Owain Gwynedd (Pryce 2011:27; Löffler 2013). Although the connection between the medieval bards, poets and minstrels and the druids has to be rejected, still these people have been tradition-bearers for their society as the study of Suggett shows (Suggett 2002). 


\subsection{Magic, shamans, medicine men and druids of the fairies}

In his chapter on 'Race in Folklore and Myth' Rhŷs connects the idea of the druids as primitive priests or medicine-men of the pre-Indo-European population of Ireland and the British Isles closely with the social Darwinist theories about the development of religion.

In fairy stories, magic is a frequent narrative element. This element, however, is taken by Rhŷs as evidence of the fairies being a primitive aboriginal people who have not developed religion yet (Rhŷs 1901: 637-8, 685). Rhŷs also uses medieval manuscripts which refer to supernatural fairy characters from Welsh or Irish medieval tradition, such as Arawn, king of Annwn, from the First Branch of the Mabinogi, Gwyn ap Nudd and Midir of Brí Léith. Arawn is called "arch-enchanter" by Rhŷs (Rhŷs 1901: 637). In the case of Gwyn and Midir, Rhŷs' translation and interpretation of the medieval sources are created in a way that supports his idea about the British and Irish aborigines, respectively, being adept at magic.

The earliest mention of Gwyn in Welsh literature is a poem in the Black Book of Carmarthen (BBC: 71-3). It is a dialogue between Gwyn ap Nudd and Gwyddno Garanhir. Asked for his name, Gwyn answers with the line "hud im gelwir e guin mab nud". In this line hud is an affirmative preverbal particle (Evan 1989:170-1), and the phrase can be translated 'Thus I'm called Gwyn ap Nudd'. Translating hud in the sense of a preverbal particle has been suggested by various translators who pre- or post-date Rhŷs (Skene 1868: 210; Rowland 1990: 506; Rüdiger 2012a: 85; GPC). Rhŷs, however, translates the name of Gwyn as "Hûd Gwyn" i.e. "White spell or White magic" (Rhŷs 1888: 562):

In an ancient poem in the Black Book of Carmarthen, Gwyn is made to give his name as Hûd Gwyn, 'the White Spell or White Magic'.

In this context it is noteworthy that hud with the meaning 'magic' appears only in the fourteenth-century texts (GPC), whereas the Black Book was presumably written in the thirteenth century (Huws 2000: 70). The dialogue between Gwyn and Gwyddno is even older and most probably predates the middle of the twelfth century (Rowland 1990: 389).

In the case of Midir, Rhŷs claims that Midir was not a warrior but a wizard:

Now it is true that the fairy Mider is described as resembling the other heroes of Irish story, in having golden yellow hair and bright blue eyes, but he differs completely from them in being no warrior but a great wizard.

(Rhŷs 1901: 681)

It is difficult to understand this statement, for Tochmarc Etaine describes Midir 
as a warrior (TE). ${ }^{19}$ Rhŷs also points out that Midir was the master of three dwarfs. Rhŷs concludes that there was a pygmy race, which formed the lowest stratum, and that they merged with a slightly more advanced people who were warlike and had a notion of paternity, namely the Picts. The latter possibly adopted their magic from the sid dwellers, i.e. the pygmy population (Rhŷs 1901: 685). Rhŷs focuses strongly on the meaning of the word cor (Welsh 'dwarf') describing a pygmy mounddweller (Rhŷs 1901: 675). Rhŷs sees parallels to the dwarf (corr) accompanying Edern ap Nudd (Rhŷs 1901:681). Moreover, Rhŷs believed the word corr to be Irish, and also refers to Stokes' translation of The Second Battle of Moytura in which Stokes translated the Irish word corrguinigh as 'sorcerer' (Stokes 1891: 76-7). For Rhŷs, the linguistic considerations seem to underpin his notion that the little people were 'consummate magicians' (Rhŷs 1901: 681). Indeed, Stokes, too, sees the texts of the medieval manuscripts as windows on the prehistoric past for he refers to Rhŷs with the following words:

The value of our story (corrupt and incomplete as it is) to students of mythology and folklore appears to me considerable, but can be properly estimated by scholars like Mr. Lang, Prof. Rhŷs, M. Gaidoz and Mr. Alfred Nutt, who have made a special study of the beliefs and practices of savage races.

(Stokes 1891: 56)

As for the practitioners of magic in the ranks of the little people, druids, shamans and medicine men are used by Rhŷs as interchangeable terms (1901: 658). The idea that the druids were enchanters and the equivalent of the magi of Egypt known from the Pentateuch (Rhŷs 1901:631) may have been facilitated by the classical authors (for instance, Pliny the Elder considered the druids as the magi, HN 16, 249251). ${ }^{20}$ Rhŷs however, follows the ideas of Cririe and Roberts, who was one of the first to euhemerise the fairies as druids in hiding (Cririe et al. 1803: 347; Roberts 1815: 192-201). Rhŷs, too, follows Roberts' interpretation of the changeling stories as child stealing by the druids' hidden communities, only that in the case of Rhŷs the community of the druids is the aboriginal population. Moreover, Rhŷs adds

19. After the description of the physical appearance of Midir TE continues:

Thereupon he came up to Eochaid. Then Eochaid said, 'Welcome to the warrior whom we do not know.' 'Tis for that we have come,' said the Warrior. 'We know thee not,' said Eochaid. 'I know thee, however,' replied the warrior. 'What is thy name?' said Eochaid. 'Not famous,' said he, 'Midir of Brí Léith' (TE: 175-7).

20. Nibil habent Druidae - ita suos appellant magos - visco et arbore, in qua gignatur, si modo sit robur, sacratius, 'Nothing do the Druids - thus they call their wise men-hold more sacred than the mistletoe and the tree on which it grows provided it is an oak' (my trans.). Cf. Vulgate Mt 2.1: Cum ergo natus esset Jesus in Bethlehem Juda in diebus Herodis regis, ecce magi ab oriente venerunt Jerosolymam. 
racial aspects claiming that the inferior aborigines stole children to improve their own poor stock. Rhŷs writes:

The other fairies, when kidnapping, it is true preferred the blond infants of other people to their own swarthy brats, which, perhaps, means that it was a policy of their people to recruit itself with men of the superior physique of the more powerful population around them.

(Rhŷs 1901: 668)

This shows a fully-fledged racist euhemerisation of the fairies. As there had been also fairy tribes of light complexion mentioned in the tradition and some prominent characters such as Midir were depicted as having blond hair, Rhŷs had to find explanations for these tales that fitted his theory. He suggested that the tales of the blond fairies should not be considered with the rest of the fairy traditions, as they were related to a late settlement of "a family or group of families from without" (Rhŷs 1901: 668). In the case of Midir, the words of Rhŷs seem implicitly to suggest that his description just follows a literary stereotype:

Now it is true that the fairy Mider is described as resembling the other heroes of Irish story, in having golden yellow hair and bright blue eyes, but he differs completely from them in being no warrior but a great wizard.

(Rhŷs 1901: 680)

According to the racial theory Rhŷs applied to the fairy traditions, Midir as a king of the fairies should share the physical appearance of either the pygmy or 'Pictish' people of swarthy complexion (Rhŷs 1901: 683). This appearance would be in agreement with the theories of Beddoe and his index of nigrescence. ${ }^{21}$ As I have mentioned, Rhŷs sees the description of the fairies as evidence for the physical appearance of a primitive people. Seen from the perspective that physical appearance can also be used to describe otherness, the narrative motifs describe the fairies as being either of supernatural beauty or of abysmal ugliness, both extremes exceeding human beauty or ugliness. Thus, the fairies are set apart from the human society, regardless of whether they are blond or black-haired. In the case of Midir, the medieval author has chosen the combination of yellow (golden/blond) hair and blue eyes, a combination of colours which is found in the description of other heroes as well. We might recall the description of Cormac in Echtra Cormaic i Tir Tairngiri ocus Ceart Claidib Cormac in which the king's visual aspect is depicted as having "hair braids slightly curled all-golden upon him" and "like blue-bells... eyes" (Stokes 1891a: 203-4).

21. See section 2.5 above. 
It is obvious that the colouring of hair skin and eyes play an important role in the racial theory of Rhŷs, so that he even contests the authenticity of the description of Midir by the medieval scribe. According to Rhŷs' model of the prehistoric past, Midir should be a member of an ethnic group with a darker colouring. The colouring of the skin as a racial marker is taken from the theories of Beddoe, ${ }^{22}$ which Rhŷs was familiar with (Rhŷs 1901: 667).

There was also a close connection between Rhŷs and other scholars who were involved in the development of social Darwinist evolutionary theories, for instance through their activity in the Committee of the British Association for the Advancement of Science founded in 1893. Board members of this committee were John Beddoe who had published an index of nigrescence for the races of Britain in 1885, Charles Darwin's cousin Francis Galton who had introduced eugenics in 1883, Joseph Anderson and John Romilly Allen who both represented the society of Antiquaries for Scotland, and John Rhŷs (Hammond 2006).

Rhŷs refers also to MacRitchie's theories which he calls "very instructive" regarding the Picts and he recommends the physiognomic theories of Sayce (Rhŷs 1901: 682). Sayce writes in The Races of the Old Testament:

Though the small dark Iberians of the British Isles intermingled with the blond Aryan Kelt centuries ago, no new type has been originated. To the present day the socalled Keltic race preserves in all their purity the two ethnological types of which it is composed, and even in the same family it often happens that some of the children belong to the one type, others to the other. Mixture of blood results only in sterility or reversion to an ancestral type-atavism, as it is usually termed, not a new race.

(Sayce 1891: 33-34)

\section{John Rhŷs' aims}

Having now given a possible alternative for the interpretation of the narrative motifs used as historical evidence by Rhŷs, it could be asked for what reasons he favoured the fairy euhemerisation theory, for other members of the Folklore Society, e.g. Andrew Lang, stressed the spiritual aspects for understanding the fairy traditions. These reasons might be discovered when looking at the impact Rhŷs' model of Britain's prehistoric past

Based on his model of the prehistoric past, Rhŷs states that, in contrast to the primitive British aborigines from the Stone Age, the ancestors of the Welsh are Celtic, that the influence of the aboriginal population on the Brythons was smaller than in the case of the Goidels:

22. See sections 2 and 3 above. 
Thus we may safely assume Welsh, Cornish and Breton to be freer from the influence of the non-Aryan element native to the British Isles than the Goidelic dialects can well have been.

(Rhŷs 1890/91: 4)

Moreover, Rhŷs stresses that both Goidels and Brythons are Aryan tribes. We have also witnessed that by designing his particular model of Britain's prehistoric of the past, Rhŷs rejects the English stereotype that Wales was the stronghold of magic, and he does so by attributing this negative stereotype to a prehistoric aboriginal people. Matthew Arnold, too, stressed the fact that the Britons/Welsh were an Aryan people, but he described the Celts (and therefore also the Welsh) as being in possession of another kind of magic:a kind of nature magic, a romantic attribute (Arnold 1891:108). About two decades later Evans-Wentz (1911) would develop this idea further.

Rhŷs, on his part, emphasises that an aboriginal, non-Aryan element contributed to the present population of the British Isles, but he stresses that this element was equally strong present in the English population. Furthermore, Rhŷs emphasises that the Welsh are of Aryan descent, as are the English people, and therefore the Welsh cannot be considered being inferior to the English. Both people are considered equal in terms of respective amount of their Aryan and non-Aryan heritage. In The Welsh People by Rhŷs and David Brynmor-Jones (1900:31), we read:

Reverting for a moment to the chief races constituting the Welsh people, the Celtic or Aryan consisting of Goidels and Brythons, and the non-Aryan consisting of the Aboriginal population, we may say that their relative proportions to one another may be treated as little disturbed by immigrants from Ireland or even from England; for the average Englishman is at most not much more Aryan than the average Welshman.

(Rhŷs \& Brynmor-Jones 1900: 31)

Rhŷs' urgent wish to show that the Welsh are not underdeveloped can be understood when looking at contemporary evolutionary theories of history which were put forward by the Oxford school of Germanist historians, with Bishop Stubbs, J. R. Green and E. A. Freeman being important advocates of this school of thought (Williams 2014: 54-63), influenced by the earlier work of Kemble. Their evolutionary model of history identified 'degenerate races' which had been subdued by Germanic tribes (Kemble 1876:232) or 'perishing people' such as the people of the old Celtic civilisation which had been destroyed by the Romans (Stubbs 1883: 2-39).

In contrast to the theories of the Saxonist historians whose ideas were promoted by The Times from 1842 onwards stressing the racial inferiority of the Celtic people (Williams 2014: 60), Rhŷs developed a model of the prehistory of the British Isles, which puts the Anglo-Saxon and the Brython on one level. When The Welsh 
People was published at the beginning of the twentieth century, its launch coincided with a period in which the Welsh language movement strengthened (Day \& Suggett 1985), and thus the work of Rhŷs rejected the earlier stereotype of Welsh being an inferior language and supported the movement by providing a historical background which showed Welsh and English on the same level. It is noteworthy that Rhŷs' work can be read as model of history which is apt to reject the understanding of history by a school of historians who strongly promoted an alleged superiority of what they called the 'Teutonic race' over the 'Celtic race'.

\section{Analyzing the use of fairy traditions: A folklorist's question}

So far as the explanations how and why Rhŷs used the fairy traditions to support his model of Britain's prehistoric past go, it may be interesting to investigate whether the study of the fairy legends adds another meaning to the theories Rhŷs invoked, such as euhemerising the fairies or neglecting the theory that the fairies were spiritual beings - as voiced, for example, by Andrew Lang (Kirk 1933) or by EvansWentz (1911), who did not follow Rhŷs in his euhemerist theory about the fairies.

Rhŷs attributes all stereotypes he wants not to be attached to Welsh society to an aboriginal British people which has become conflated with the fairies. This is only possible by accepting a euhemerist theory about the origin of the fairies. This interpretation is supported in his own writing:

Thus the Aboriginal non-Aryan ideas as to marriage might, conceivably, have survived long in the modified form of a tendency to take somewhat too lenient a view of immorality.

(Rhŷs, 1900: 23)

Therefore, Rhŷs' drafting of Britain's prehistory shows how Rhŷs tries to clear his countrymen of the stigma of underdevelopment. In addition, it is apparent that Rhŷs uses traditional motifs in a very traditional way: he devises a prehistoric people with a culture that comprises all features he does not want to attribute to his own Welsh society.

\section{Conclusion}

This paper has shown that Rhŷs used fairy traditions to draft a model for the prehistoric past of the British Isles. The interpretation he found for the fairy traditions and his euhemerization of the fairies is governed by his assumption that an aboriginal people was responsible for non-Aryan elements scholars believed to have discovered in language and culture. Rhŷs considers elements from contemporary research concerning matriarchy, the development of religion, racial theories based on social Darwinist ideas, and evolutionary theories in the field of archaeology and linguistics. The model of Britain's prehistoric past as introduced by Rhŷs 
aims at defending the Welsh people and the Welsh language against the prejudice of being inferior to English language and the Anglo-Saxon culture. Rhŷs' theories influenced J. E. Lloyd's theories about the origin of the Goidels (Pryce 2013). Rhŷs's model proved to be very long-lived and influential. Until the end of the twentieth century, his fairy euhemerisation theory found supporters, among them R. Gwyndaf of St. Fagans National History Museum..$^{23}$ Moreover, it inspired novelists, who invoked a hidden realm of a primitive people on British ground, such as Arthur Machen (Arthur Llewellyn Jones) in his well-known short story The Shining Pyramid. Likewise, Rhŷs' ideas on the prehistory of Britain can be found in popular novels, and by this way they are still communicated to wider audiences. ${ }^{24}$

Rhŷs used traditional elements of folklore to flesh out his theory which was based on evolutionary models of anthropology, ethnology, archaeology and linguistics. At the same time, Rhŷs' reading of folklore established a historical model which was apt to challenge the Teutonist evolutionary models of British history. Moreover, by applying an euhemerisation theory to the study of the Welsh oral tradition, the tales had been cleared off their interpretation as superfluous and superstitious. On the contrary, deemed as representing memory of prehistoric peoples, the tales gained scientific importance. The folk tradition was turned from being the one consisting of 'old wives' tales to be ignored into a store of potentially historically important material. For John Rhŷs, this aspect was crucial, which he deeply identified with: "my education, such as it was, had been of a nature to discourage all interest in anything that savoured of heathen lore and superstition" (Rhŷs 1901: viii). He writes in Celtic Folklore "and those who may think that these legends here recorded are childish and frivolous, may rest assured that they bear on questions which could not themselves called either childish or frivolous" (Rhŷs 1901:1).

Thus, Rhŷs' study of folklore can be seen as important work which encouraged the subsequent generation of Welsh scholars to cherish their folklore heritage and the language. In the end, as this study originated in an investigation on the use of folk tradition, I shall conclude with the words of Alan Dundes the truth of which has been proven in my opinion by the present example: "I believe the folklorist can, by analysing folklore, discover general patterns of culture, and I would maintain further that knowledge of such patterns can provide the means of raising levels of consciousness" (Alan Dundes 1980:x).

Bangor University

23. In Welsh Folktales, R. Gwyndaf (1999) writes "Fairy lake legends (e.g. Llyn y Fan Fach, 44) may suggest a type of primitive lake dwellings (crannog)."

24. Suffice it to mention two novels reminiscent of Rhŷs' theories, such as The Mist of Avalon by Zimmer-Bradley (1982) and the retelling of the Mabinogion by Evangeline Walton (1974). 


\section{Abbreviations}

BBC-Jarman, A.O.H., \& Jones, E.D., eds., 1982, Llyfr Du Caerfyrddin, Cardiff.

GPC-Geiriadur Prifysgol Cymru, Cardiff (available at http://www.wales.ac.uk/dictionary, last accessed 09.08.2019).

HN-Friedrich, K., and Mayhoff, T., eds., 1906, Pliny the Elder. Naturalis Historia, Leipzig (available at http://www.perseus.tufts.edu, last accessed 25.08.2019).

TE-Bergin, O, \& Best, R.I., ed. and trans., The Wooing of Etain, electronic edition by B. Hazard: CELT: Corpus of Electronic Texts, University College, Cork (available at http://www.ucc.ie/celt, last accessed 13.03.2017).

SV-Biblia Sacra Vulgata (English standard version), Die Deutsche Bibelgesellschaft (available at http://www.bibelwissenschaft.de, last accessed 25.08.2019).

\section{References}

Arnold, M., 1891, The Study of Celtic Literature, London.

Beddoe, J., 1885, The Races of Britain: A Contribution to the Anthropology of Western Europe, London.

Bennett, G., 1993, 'Folklore Studies and the English Rural Myth', Rural History 4, 77-91. Bachofen, J.J., 1861, Das Mutterrecht. Eine Untersuchung über die Gynaikokratie der alten Welt nach ihrer religiösen und rechtlichen Natur [Mother Right. An Investigation in Gynaicocracy in the Old World according to its religious and legal Nature], Stuttgart.

Birkhan, H., 2009, Nachantike Keltenrezeption. Projektionen keltischer Kultur [Postclassical Reception of the Celts. Projections of Celtic Culture], Wien.

Brantlinger, P., 2018, 'Imperialism', Victorian Literature and Culture 46, 735-39.

Carroll, M.P., 1988, 'Some Third Thoughts on Max Müller's Solar Mythology', European Journal of Sociology 26, 263-281.

Chambers, R., 1845, Vestiges of the Natural History of Creation, New York (2nd ed. from the 3rd London ed.).

Charles-Edwards, T.M., 2013, 'John Rhŷs, Celtic Studies and the Welsh Past', in:Evans, N., \& Pryce, H., eds., Writing a Small Nation's Past: Wales in Comparative Perspective, 1850-1950, Burlington (VT).

Charles-Edwards, T.M., 2019, 'John Rhŷs and the Jesus Chair of Celtic at Oxford', Cambrian Medieval Celtic Studies 77, 33-46.

Clark, G., 1966, 'The Invasion Hypothesis in British Archaeology', Antiquity 40, 172-189. Clarkson, T., 2012, The Picts, Edinburgh.

Constantine, M.-A., 2007, The Truth Against the World, Cardiff.

Cririe, J., Byrne, W., \& Walker, G., 1803, Scottish Scenery: or, Sketches in Verse, Descriptive of Scenes chiefly in the Highlands of Scotland, London.

Darwin, C., 1859, On the Origin of Species by Means of Natural Selection, or the 
Preservation of favoured Races in the Struggle for Life, London.

Davies, L.M., 1990, 'John Rhŷs a Llên Gwerin', Barn (Mehefin 1990), 329.

Davies, S., 2018, 'The Lady of the Lake and Legend Transmission'. In: Barlow, R., ed., Transactions of the Physicians of Myddfai Society, 2011-2017, Dinefwr, 9-17.

Dawkins, W.B., 1880, Early Man in Britain and his Place in the Tertiary Period, London. Day, G. \& Suggett, R. 'Conceptions of Wales and Welshness: Aspects of Nationalism in Nineteenth-Century Wales' in: Rees, G., Burja, J., Littlewood, P., Newby, H., \& Rees, T.L., eds., Political Action and Social Identity: Class, Locality and Ideology, London, 91-115. De la Motte Fouqué, F.,1953, Undine, Stuttgart.

Dorson, R., 1968, The British Folklorists, London.

Dundes, A., 1980, Interpreting Folklore, Bloomington

Edwards, N. \& Gould, J., 2013 'From Antiquarians to Archaeologists in nineteenth-century Wales: The Question of Prehistory', in:Evans, N., \& Pryce, H., eds., Writing a Small Nation's Past. Wales in Comparative Perspective, 1850-1950, Cardiff (electronic Kindle edition).

Egerton, F., 1848, Guide to Northern Archaeology by the Royal Society of Northern Antiquaries of Copenhagen edited for the use of English Readers, London.

Engels, F., 1886, Der Ursprung der Familie, des Privateigenthums und des Staats [The origin of the family, private poperty and the state], Hottingen-Zürich.

Evan, D.S., 1989, A Grammar of Middle Welsh, Mediaeval and Modern Welsh series, Dublin. Evans, J.Gwenogvryn, ed., 1932, The Black Book of Carmarthen, in: Mühlhausen Nachlass (MS collection), Box 3, University Library Special Collection, Tübingen.

Evans, N., \& Pryce, H., 2013, 'Writing a Small Nation's past: States Race and Historical Culture' in:Evans, N., \& Pryce, H.,eds., Writing a Small Nation's Past. Wales in Comparative Perspective, 1850-1950, Cardiff (electronic edition).

Evans, T., \& Evans, S.J., ed., 1902, Drych y Prif Oesoedd [Mirror of the First Ages], Bangor (reprint of the 2nd or 1740 edition).

Evans, V., 1914-15, 'The Late Right Honourable Sir John Rhŷs. Appreciation by Some of his Friends and Fellow-workers', Transactions of the Honourable Society of Cymmrodorion 1914-15,195-247.

Evans, W.G., 1995, 'John Rhŷs a byd Arolygwr ei Mawrhydi yng Nghymru Oes Victoria' ['John Rhŷs and the World of Her Majesty's Inspector in Victorian Wales'], Llên Cymru, 18, 340-348.

Evans-Wentz, W.Y., 1911, The Fairy-Faith in Celtic Countries. Reprint, London: Forgotten Books, 1994.

Falileyev, A., 2019, 'Professore Giovanni Rhys and Some of his Gleanings in the Italian Field of Celtic Epigraphy', Cambrian Medieval Celtic Studies 77, 97-110.

Frazer, J. \& Williams, M.A., 2004/2006, 'Rhŷs [formerly Rees], Sir John', Oxford Dictionary of National Biography, version of 25 May 2006 (available at http: //doi. org/10.1093/ref;odnb/35734, last accessed on 14.05.2019). 
Frazer, J.G., 1890, The Golden Bough. A Study of Magic and Religion, London.

Frazer, J.G., 1894, The Golden Bough. A Study of Magic and Religion, London (reprint of the first edition from 1890).

Frazer, J.G., 1925, The Golden Bough. A Study of Magic and Religion London (reprint of the 1922 one volume abridged edition).

Grimm, J. and W., 1835, Deutsche Mythologie. Volume I, Wiesbaden.

Gwyndaf, R., 1999, Welsh Folk Tales, Cardiff.

Haddon, A.C., 1910, History of Anthropology, London.

Hammond, M. H., 2006, 'Ethnicity and the Writing of Medieval Scottish History', The Scottish Historical Review, 85: 219, 1-27.

Halliday, R.J., 1971, 'Social Darwinism: A Definition', Victorian Studies 14, 389-407. Hartland, E.S., 1891, The Science of Fairy Tales. An Inquiry Into Fairy Mythology, London.

Hartland, E.S., 1916, 'The Rt. Hon Sir John Rhŷs', Folklore 27, 110-111.

Haycock, M., 2007, Legendary Poems from the Book Taliesin, Aberystwyth

Hobson, J.A., 2006, Imperialism: A Study, New York.

Holmes, T.R., 1907, Ancient Britain and the Invasions of Julius Caesar, Oxford.

Hudson, B., 2014, The Picts, Hoboken, NJ.

Hutton, R., 1991, The Pagan Religions of the Ancient British Isles. Their Nature and Legacy, Oxford.

Hutton, R. 2009, Blood and Mistletoe. The History of the Druids in Briton, London.

Hutton, R. 2011, 'How Pagan Were Medieval English Peasants', Folklore 122, 235-249.

Huws, D., 2000, Medieval Welsh Manuscripts, Aberystwyth.

Jenkins, G.H., 2009, A Rattleskull Genius: The Many Faces of Iolo Morganwg, Cardiff. Jenkins, R.T., 1959a. 'MORRIS, LEWIS (Llewelyn Ddu o Fôn; 1701-1765), poet and scholar.' Dictionary of Welsh Biography (available at https://biography.wales/article/ s-MORR-LEW-1701, last accessed 16.06).2019]

Jenkins, R.T., 1959b. 'WILLIAMS, JOHN (Ab Ithel; 1811-1862), cleric and antiquary.', Dictionary of Welsh Biography (available at https://biography.wales/article/s-WILLJOH-1811, last accessed 18.06.2019).

Jenkins, R.T., 2001. 'LLOYD, Sir JOHN EDWARD (1861-1947), historian, and first editor of Y Bywgraffiadur Cymreig., Dictionary of Welsh Biography (available at https://biography.wales/article/s2-LLOY-EDW-1861, last accessed 18.06.2019).

Johnson, R, 2003, British Imperialism, London.

Jones, T., 1959. 'LHUYD, EDWARD (1660-1709), botanist, geologist, antiquary, and philologist.', Dictionary of Welsh Biography (available at https://biography.wales/article/s-LHUY-EDW-1660, last accessed 16 June 2019).

Kemble, J.M. 1876, The Saxons in England, London (2nd edition).

Keith, W.J., 1975, The Rural Tradition, Toronto.

Kidd, B., 1894, Social Evolution, London. 
Kirk, R., 1933, The Secret Commonwealth of Elves, Fauns and Fairies. Introduction to the 1893 edition by Andrew Lang. Introduction to the 1933 edition by R. B. Cunninghame Graham, Mineola, New York (unabridged 2008 reprint of the 1933 edition).

Kollmann, J., 1894,'Das Schweitzersbild bei Schaffhausen und Pygmäen in Europa‘ [The Image of the Swiss at Schaffhausen and pygmies in Europe], Zeitschrift für Ethnologie, 26, 189-254.

Kyllingstad, J.R., 2012, 'Norwegian Physical Anthropology and the Idea of a Nordic Master Race', Current Anthropology 53, Supplement 5, S46-S56.

Lawrence, R.M., 1898, The Magic of the Horse-shoe, Boston.

Lhuyd, E., 1707, Archaeologia Britannica, Giving some Account Additional to what Has Been hitherto Publish'd, of the Languages, Histories and Customs of the Original Inhabitants of Great Britain: From Collections and Observation in Travels through Wales, Cornwal, Bas-Bretagne, Ireland and Scotland. Vol. I. Glossography, Oxford.

Leonard, T.C., 2009, 'Origins of the Myth of Social Darwinism: The Ambiguous Legacy of Richard Hofstadter's Social Darwinism in American Thought', Journal of Economic Behaviour \& Organization 71, 37-51.

Lewin, C., 2019, 'John Rhys: A Pioneer in the Study of Manx', Cambrian Medieval Celtic Studies 77, 65-96.

Lewis, S., 2016a, 'In search of the Celtic Past: A Biography of John Rhŷs', in: Bérose-Encyclopédie international des histoires de l'anthropologie, Paris, IIAC-LAHIC; UMR8177. [12 March 2019]

Lewis, S., 2016b, 'Aboriginal Speech: Sir John Rhŷs and Racial Narrative in Victorian Language Study', in: Bérose-Encyclopédie international des histoires de l'anthropologie, Paris, IIAC-LAHIC; UMR8177. [12 March 2019]

Löffler, M., 2013, 'Failed founding Fathers and Abandoned Sources: Edward Williams, Thomas Stephens and the Young J.E. Lloyd', in:Evans, N., \& Pryce, H., eds., Writing a Small Nation's Past. Wales in Comparative Perspective, 1850-1950, Cardiff (Kindle edition).

Machen, A, 1895, The Shining Pyramid, Whitefish (repint 2004).

MacRitchie, D., 1890, The Testimony of Tradition, London.

MacRitchie, D., 1892, 'The Historical Aspect of Folklore' in: Jacobs, J., \& Nutt, A., eds., Transactions of the International Folk-Lore Congress, London, 103-112.

MacRitchie, D., 1893, Fians, Fairies, and Picts, London.

MacRitchie, D., 1894, Ancient and Modern Britons, London.

Morgan, L.H., 1877, Ancient Society, or Researches in the Lines of Human Progress from Savagery through Barbarism to Civilization, New York.

Morgan, P., 1981, The Eighteenth-Century Renaissance, Llandybie.

Morris-Jones, J., 1924/1925, 'Syr John Rhŷs', Proceedings of the British Academy 11, 187-212.

Morris-Jones, J., 2002 ‘Sir John Rhŷs: 1840-1915’, in: Lapidge, M., ed., Interpreters of Early Medieval Britain, Oxford, 51-62. 
Morse, M. A., 1999, 'Craniology and the Adoption of the Three-Age System in Britain', Proceedings of the Prehistoric Society 65, 1-16.

Müller, M., 1878, Lectures on the Origin and Growth of Religion as Illustrated by Religions of India, London.

Prichard, J.C., 1831, The Eastern Origin of the Celtic Nations proved by a Comparison of Their Dialects with the Sanskrit, Greek, Latin, and Teutonic languages Forming a Supplement to Researches into the Physical History of Mankind, Oxford.

Price, J., 1573, Historiae Brytannicae Defensio, London.

Price, T. (Carnhuanawc), 1829, An essay on the physiognomy and physiology of the present inhabitants of Britain; with reference to their origin, as Goths and Celts, London.

Pryce, H., 2011, 'Culture, Identity, and the Medieval Revival in Victorian Wales', Proceedings of the Harvard Celtic Colloquium, 31:1-40.

Rees, B., 1959, 'PRICE, THOMAS (Carnhuanawc; 1787-1848), historian and antiquary,' Dictionary of Welsh Biography (available at https://biography.wales/article/s-PRICTHO-1787, last accessed 16.06.2019).

Rhŷs, J., 1877, Lectures on Welsh Philology, London.

Rhŷs, J., 1888, Lectures on the Origin and Growth of Religion as illustrated by Celtic Heathendom, London (facsimile reprint 2008).

Rhŷs, J.,1891, Studies in Arthurian Legend, Oxford.

Rhŷs, J., 1890/91, The Rhind Lectures in Archaeology in connection with the Society of Antiquarians of Scotland: delivered in December 1889, on the early ethnology of the British Isles as printed in the Scottish Review for April 1890-July 1891, facsimile reprint 1990, Felinfach, Lampeter

Rhŷs, J., 1901, Celtic Folklore: Welsh and Manx, London (facsimile reprint 2012).

Rhŷs, J., \& Brynmor-Jones, D. 1900, The Welsh People; Chapters on their Origin, History, Laws, Language, Literature, and Characteristics, New York (2nd edition).

Rhŷs, J., 1884, Celtic Britain, London (2nd edition).

Roberts, B., 2009, 'Edward Lhwyd (c. 1660-1709): Folklorist', Folklore 120:1, 36-56.

Roberts, P., 1815, The Cambrian Popular Antiquities (Collectanea Cambrica), London. Rodway, S., 2019, 'New light on Rhys' Lectures on Welsh Philology', Cambrian Medieval Celtic Studies 77, 3-16.

Rogers, J.A., 1972, 'Darwin and Social Darwinism', Journal of the History of Ideas 33, $265-86$. Rowland, J., 1990, Early Welsh Saga Poetry, Cambridge.

Roberts, G.T., 1998, The Language of the Blue Books, Cardiff.

Rüdiger, A.H., 2012, Gwyn ap Nudd. Transfigurations of a Character on the Way from Medieval Literature to Neo-pagan Beliefs, M.A. thesis, University of Bangor.

Russel, P., 2019, 'Network of Letters: Correspondence between Rhys, Stokes, and Bradshaw', Cambrian Medieval Celtic Studies 77, 17-32.

Sayce, A.H., 1891, The Races of the Old Testament, London.

Schleicher, A., 1873, Die Darwinsche Theorie und die Sprachwissenschaft, Weimar. 
Silver, C.G., 1999, Strange and Secret Peoples: Fairies and Victorian Consciousness, Oxford. Sims-Williams, P., 2019, 'John Rhys and the Insular Inscriptions', Cambrian Medieval Celtic Studies 77, 47-64.

Skene, W.F., 1868, The Four Ancient Books of Wales, London (reprint by Forgotten Books 2007).

Spencer, H., 1864, The Principles of Biology, Vol. I, London.

Stephens, M., 1986, The Oxford Companion to the Literature of Wales, Oxford.

Stokes, W., 1891, 'The Second Battle of Moytura', Revue Celtique 12, 52-130.

Stokes, W, 1891a, 'Scél na Fir Flatha. Echtra Cormaic i Tír Tairngiri ocus Ceart Claidib Cormac', Irische Texte 3, 183-229, Leipzig.

Stubbs, W., 1883, The Constitutional History of England, Oxford.

Suggett; R., 2002, 'Vagabonds and Minstrels in Sixteenth-century Wales', in: Fox, A., \& Wolf, D., eds.,The Spoken Word: Oral Culture in Britain 1500-1850, Manchester, 138-172. Thomas, J.,1975, 'The Development of Folklore Studies in Wales 1700-1900', Keystone Folklore 20, 33-52.

Thomsen, C.J., Petersen, N.M., \& Rafn, C.C., 1836, Ledetraad til Nordisk Oldkyndighed / udg. af det Kongelige Nordiske Oldskrift-selskab [Guide to Nordic Antiquity / ed. by the Royal Nordic Antiquities company], Copenhagen.

Thorne, D., 1986, 'Map Tafodieithol John Rhŷs: Y Cefndir Ieithol', Cylchgrawn Llyfrgell Genedlaethol Cymru 24, 448-462.

Tylor, E.B, 1871, Primitive Culture: Researches into the Development of Mythology, Philosophy, Religion, Art, and Custom. Vol.I, London.

Tylor, E.B, 1920, Primitive Culture: Researches into the Development of Mythology, Philosophy, Religion, Art, and Custom. Vol.II, London.

Walton, E., 1974, Four Branches of the Mabinogion: Prince of Annwn, The Children of Llyr, The Song of Rhiannon, the Island of The Mighty, New York.

Wiener, M., 1981, English Culture and the Decline of the Industrial Spirit, Cambridge. Williams, D.R., 2009, Edward Lluyd, 1660-1709: a Shropshire Welshman, Oswestry. Williams, E. W., 2014, 'J.E. Lloyd and the Intellectual Foundations of Welsh History', Clychgrawn Llyfrgell Genedlathol Cymru 36(1), 54-97.

Williams, G.J., 1959, 'MERRICK, RICE (RHYS MEURUG) (died 1586-7), a landed gentleman, genealogist, and historian,' Dictionary of Welsh Biography (available at https:// biography.wales/article/s-MEUR-RHY-1586, last accessed 16.06.2019)

Williams, I., 1959, 'Rhŷs, Sir John (1840-1915), Celtic scholar', in: Dictionary of Welsh Biography Online. Llyfrgell Genedlaethol, Aberystwytht(available at http://wbo.llgc. org.uk/en/index.html, last accessed 15.06.2014).

Williams, R., 1973, The Country and the City, London.

Winstanley, L., Angus, J.M., \& Lloyd, J.E., eds., 1880, 'The Debating Society: Public Debate "On the Extension of Frachise to Women", University College of Wales Magazine II (5), 224-231 (available at http://hdl.handle.net/10107/2045935, last accessed 13.08.2019). 
Wood, J., 1992, 'The Fairy Bride Legends in Wales', Folklore 103, 56-72.

Wood, J., 1997, 'Perceptions of the Past in Welsh Folklore Studies', Folkore 180,93-102.

Wood, J., 2005, 'Folk Narrative Research in Wales at the Beginning of the Twentieth Century: The Influence of John Rhŷs (1840-1916)', Folklore 116, 325-341.

Worsaae, J.J.A.., 1849, The Primeval Antiquities of Denmark, London. Trans. W. J. Thoms. Zimmer-Bradley, M., 1982, The Mists of Avalon, New York. 